\title{
A Study on Participation of Youth in Agriculture and Allied Sectors in Warangal District of Telangana State
}

\author{
D. Uttej ${ }^{1 *}$, I. Sreenivasa Rao ${ }^{2}$, M. Sreenivasulu ${ }^{3}$ and A. Madhavi Lata ${ }^{4}$ \\ ${ }^{1}$ Department of Agricultural Extension, Professor Jayashankar Telangana State Agricultural \\ University, Hyderabad, India \\ ${ }^{2}$ Extension Education Institute, Hyderabad, India \\ ${ }^{3}$ Agricultural Extension, ${ }^{4}$ Department of Agronomy, College of Agriculture, Rajendranagar, \\ Hyderabad, India \\ *Corresponding author
}

\section{Keywords}

Agriculture, Allied Sectors, Warangal District

Article Info

Accepted:

26 May 2019

Available Online:

10 June 2019

\section{A B S T R A C T}

Youth are the most potent segment of the population of a country. The youth of today are the hopes of tomorrow. They are the real spirit for future agriculture of the country. Forces that shape and influence youth today will be the forces that dominate our country tomorrow. Youth look not only for a livelihood, but for dignity and for purpose and meaning in their lives. Youth make up approximately one-fifth of the total population in many countries in developing and emerging economy regions. The socio-economic development and prosperity of rural areas depends, to a considerable extent, on the type of youth living in rural areas, because the rural youth have abilities to orient themselves to go along the main stream of the development process. It is a known fact that hardly few youth are practising agriculture, even though, majority of the rural youth have vigour and zeal to excel in agricultural and allied activities. In this context, it is worthwhile to know the extent of participation of youth in agriculture and allied activities. Keeping this in view, a study was conducted in Warangal district of Telangana state with a total sample of 120 youth who are selected using simple random sampling technique. The objective of the study was to know the extent of participation of youth in agriculture and allied activities. The data was collected from primary sources with structured interview schedule. The study employed descriptive statistics and rank order method to analyse the data. The study indicated that more than half $(51.7 \%)$ of the total youth had medium level of participation in agriculture and allied activities followed by low (25.0\%) and high (23.3\%). Among male youth majority (53.4\%) had medium level of participation in overall agriculture and allied activities followed by high (28.2\%) and low (18.4\%). Among female youth exactly half $(50.0 \%)$ of youth had medium level of participation in overall agriculture and allied activities followed by low (31.6\%) and high (18.4\%).

\section{Introduction}

Agriculture remains critical to the economic development of most if not all developing countries across the globe. The agricultural future of most developing countries may be bleak if the bulk of the production efforts are left in the hands of aged subsistent farmers who presently constitute the major farming population. This is because the productivity level of the aged farmers cannot meet the food and fiber needs of the rapidly growing population. Consequently, fostering youth involvement in agriculture is fundamental. 
Youth are an important and vital segment of human resources that can shoulder the responsibility of development including agriculture.

It is imperative for the nation to produce food not only to feed its one billion plus human population but also for an equal number of livestock. At this juncture young minds with creativity and achievement motivation seemingly can handle impossible tasks such as climate change adaptation and mitigation and enduring malnutrition. Generally, youth are willing to adopt new ideas and technologies and therefore they can easily transform the present status of farming.

The youth could be the ideal catalyst to change the poor image of persons involved in farming, especially in the rural communities given their greater possibility to adapt new ideas, concept and technology which are all important to changing the way farming is practiced and perceived. Moreover, with the rise in their aspirations, their exposure to new age media like internet, smart phones, television the rural youth are now looking for a better life and job.

The only way to stop them from leaving the villages is by ensuring better economic prospects for them in farming and improving the quality of life in the rural belt.

Conventionally, period from adolescence to middle age is termed as youth. Age constitute the determining characteristics in the definition of Youth by various agencies. UN adopted the age group 15 to 24 for defining youth.

The National Youth Policy initially in (2003) defined the youth as in the age group 13-35. However, National Youth Policy, 2014 modified it and defined 'youth' as persons in the age group of 15-29 years.
According to 'World Population Prospects: The 2015 revision' Population Database of United Nations Population Division, India has the world's highest number of youths, with 242 million-despite having a smaller population than China, which has 185 million young people.

As per India's Census 2011, Youth (15-24 years) in India constitutes one-fifth (19.1\%) of India's total population.

Savitha (2011) in her study on Participation of rural youth in agriculture revealed that majority $(80.00 \%)$ of the rural male youth participated in ploughing, followed by FYM broadcasting $(73.33 \%)$, cleaning $(60.00 \%)$, leveling (53.33\%) and 31.67 per cent of rural male youth were participated in clod crushing.

Hadagali Vishwanath (2013) in his study on a study on Aspirations and participation of rural youth practicing agriculture and allied activities found about overall participation that as high as 41.01 per cent of rural youth had high level of participation in agriculture, whereas, 34.16 and 25.83 per cent of them were having medium and low level of participation, respectively.

\section{Materials and Methods}

Ex-post-facto research design was adopted for the study. Warangal district of Telangana state was selected. Four mandals in the district and 3 villages from each mandal were selected using simple random sampling technique. Thus, a total of 12 villages were selected. From each village 10 respondents were selected using simple random sampling technique thus constituting 120 respondents for the study. Participation is operationalised as "active or passive involvement of youth in various activities of agriculture and allied sector". 


\section{Active participation}

Youth participate by taking initiatives independent of family members or other external factors to change systems.

\section{Passive participation}

Youth participate by being told what has been decided or instructed by family members.

The extent of participation was measured by using the schedule developed for study. To identify the activities performed by youth in agriculture and allied activities, a list of various activities were listed based on package of practices and review of literature. The activities performed by the respondents were scored under five point continuum viz., active participation regularly, active participation occasionally, passive participation regularly, passive participation occasionally and no participation with scoring of $4,3,2,1,0$ respectively.

The maximum and minimum score one could get is 16 and 0 in General activities, 48 and 0 in agriculture, 44 and 0 in horticulture, 36 and 0 in dairy, 32 and 0 in sheep and goat rearing and 32 and 0 in poultry rearing. Based on the total cumulated score obtained under each sector the youth were classified in to three category viz., low, medium and high participation level based on Quartile deviation.

\section{Results and Discussions}

The results from Table 1 indicate that, In General activities majority (53.3\%) of the total youth had medium level of participation followed by low (30.0\%) and high (16.7\%). In Agricultural activities half (50.0\%) of the total youth had medium level of participation followed by low (27.5\%) and high (22.5\%). In Horticultural activities half $(50.0 \%)$ of the total youth had low level of participation followed by high (32.5\%) and medium (17.5\%). In Dairy 44.2 per cent of the total youth had low level of participation followed by high $(28.3 \%)$ and medium (27.5\%). In Sheep and goat rearing majority $(72.5 \%)$ of the total youth had low level of participation followed by medium $(21.7 \%)$ and low $(5.8 \%)$. In poultry farming half $(50.8 \%)$ of the total youth had low level of participation followed by high $(29.2 \%)$ and medium $(20.0 \%)$.

Overall more than half $(51.7 \%)$ of the total youth had medium level of participation in agriculture and allied activities followed by low (25.0\%) and high (23.3\%). Among male youth majority $(53.4 \%)$ had medium level of participation in overall agriculture and allied activities followed by high $(28.2 \%)$ and low $(18.4 \%)$. Among female youth exactly half $(50.0 \%)$ of youth had medium level of participation in overall agriculture and allied activities followed by low (31.6\%) and high (18.4\%).

The possible reason might be as youth had concentrated more on higher studies instead of participating in agriculture and allied activities in their early stages their participation was medium.

Further parents of youth do not want their children to participate in agri allied activities. These factors might have lead to low to medium participation of youth in agriculture and allied activities.

The participation of rural youth in agriculture and allied activities was found to be medium. To make rural youth participate more in agriculture and allied activities, it is implied that creation of basic infrastructures like processing and value addition facilities at village level with relevant technical support will make agriculture and allied sectors as profitable ventures. 
Table.1 Extent of participation of youth in agriculture and allied activities $N=120$

\begin{tabular}{|c|c|c|c|c|c|c|c|}
\hline \multirow{2}{*}{$\begin{array}{l}\text { S. } \\
\text { No. }\end{array}$} & \multirow[t]{2}{*}{ Category } & \multicolumn{2}{|c|}{ Male } & \multicolumn{2}{|c|}{ Female } & \multicolumn{2}{|c|}{ Total } \\
\hline & & $\mathbf{F}$ & $\%$ & $\mathbf{F}$ & $\%$ & $\mathbf{F}$ & $\%$ \\
\hline I & \multicolumn{7}{|c|}{ General Activities } \\
\hline 1. & Low & 8 & 13.4 & 28 & 46.6 & 36 & 30.0 \\
\hline 2. & Medium & 37 & 61.6 & 27 & 45.0 & 64 & 53.3 \\
\hline \multirow[t]{2}{*}{3.} & High & 15 & 25.0 & 5 & 8.4 & 20 & 16.7 \\
\hline & Total & 60 & 100 & 60 & 100 & 120 & 100 \\
\hline II & \multicolumn{7}{|c|}{ Agriculture } \\
\hline 1. & Low & 8 & 13.4 & 25 & 41.6 & 33 & 27.5 \\
\hline 2. & Medium & 28 & 46.6 & 32 & 53.4 & 60 & 50.0 \\
\hline \multirow[t]{2}{*}{3.} & High & 24 & 40.0 & 3 & 5.0 & 27 & 22.5 \\
\hline & Total & 60 & 100 & 60 & 100 & 120 & 100 \\
\hline III & \multicolumn{7}{|c|}{ Horticulture } \\
\hline 1. & Low & 28 & 46.6 & 32 & 53.4 & 60 & 50.0 \\
\hline 2. & Medium & 12 & 20.0 & 9 & 15.0 & 21 & 17.5 \\
\hline \multirow[t]{2}{*}{3.} & High & 20 & 33.4 & 19 & 31.6 & 39 & 32.5 \\
\hline & Total & 60 & 50 & 60 & 100 & 120 & 100 \\
\hline IV & \multicolumn{7}{|l|}{ Dairy } \\
\hline 1. & Low & 29 & 48.4 & 24 & 40.0 & 53 & 44.2 \\
\hline 2. & Medium & 16 & 26.6 & 17 & 28.4 & 33 & 27.5 \\
\hline \multirow[t]{2}{*}{3.} & High & 15 & 25.0 & 19 & 31.6 & 34 & 28.3 \\
\hline & Total & 60 & 50 & 60 & 100 & 120 & 100 \\
\hline $\mathbf{V}$ & \multicolumn{7}{|c|}{ Sheep and Goat rearing } \\
\hline 1. & Low & 40 & 66.6 & 47 & 78.4 & 87 & 72.5 \\
\hline 2. & Medium & 14 & 23.4 & 12 & 20.0 & 26 & 21.7 \\
\hline \multirow[t]{2}{*}{3.} & High & 6 & 10.0 & 1 & 1.6 & 7 & 5.8 \\
\hline & Total & 60 & 100 & 60 & 100 & 120 & 100 \\
\hline VI & \multicolumn{7}{|c|}{ Poultry farming } \\
\hline 1. & Low & 34 & 56.6 & 27 & 45.0 & 61 & 50.8 \\
\hline 2. & Medium & 8 & 13.4 & 16 & 26.6 & 24 & 20.0 \\
\hline \multirow[t]{2}{*}{3.} & High & 18 & 30.0 & 17 & 28.4 & 35 & 29.2 \\
\hline & Total & 60 & 100 & 60 & 100 & 120 & 100 \\
\hline VII & \multicolumn{7}{|c|}{ Overall Participation in Agri allied activities } \\
\hline 1. & Low & 11 & 18.4 & 19 & 31.6 & 30 & 25.0 \\
\hline 2. & Medium & 32 & 53.4 & 30 & 50.0 & 62 & 51.7 \\
\hline 3. & High & 17 & 28.2 & 11 & 18.4 & 28 & 23.3 \\
\hline & Total & 60 & 50 & 60 & 100 & 120 & 100 \\
\hline
\end{tabular}




\section{References}

National Youth Policy of India. 2014. Ministry of Youth Affairs and Sports.

Savita Nashi, B. 2011. Participation and decision making of rural youth in agriculture. M.Sc. (Ag.) Thesis. University of Agricultural Sciences,
Dharwad.

Viswanatha, H., Manjunatha, B.N and Lakshminarayana, M.T. 2014. Aspirations and problems of rural youth practicing agriculture. The Mysore Journal of Agricultural sciences. 48 (4): 583-588.

\section{How to cite this article:}

Uttej, D., I. Sreenivasa Rao, M. Sreenivasulu and Madhavi Lata, A. 2019. A Study on Participation of Youth in Agriculture and Allied Sectors in Warangal District of Telangana State. Int.J.Curr.Microbiol.App.Sci. 8(06): 2954-2958. doi: https://doi.org/10.20546/ijcmas.2019.807.366 